\title{
Vulnerability assessment as a support for a sustainable coastal city: a case study of La Paz, Mexico
}

\author{
A. González-Baheza \& O. Arizpe \\ Laboratorio de Ecología de Sistemas Costeros, \\ Universidad Autonoma de Baja California Sur, Mexico
}

\begin{abstract}
Coastal zone (CZ) and adjacent land areas supports more than 50\% of human population and eight of the top ten largest cities in the world. They are exposed to natural hazards and climate change induced stresses, which have led to focus as a relevant issue, the assessment of its vulnerability in many regions of the planet. Assessment and monitoring of vulnerability models in $\mathrm{CZ}$ should be able to influence the environmental policies, and guiding decision makers to provide the main elements for the sustainability of any coastal city. The case of study La Paz (CS) is the capital city of the biggest coastal extension state of Mexico. CS was regionalized based on biotic, natural landscape and socio-economic factors within geographic information systems, obtaining 74 environmental units (EnvU). Assessment on each EnvU with a coastal vulnerability model, used physical, environmental and socio-economic indicators and integrated indices, considering three main elements: a fixed component defined by Coastal Vulnerability Index $(\mathrm{CVI})=$ Pressure Index (PI) + Fragility Index (FI). Nearly $38 \%$ of EnvU and over $60 \%$ of CS showed high and very high FI, including capital city. Only $7 \%$ of EnvU and $14 \%$ of CS presented high and very high PI. Nearly a third of EnvU had high and very high CVI, mainly on La Paz and southwest of CS without actual human pressure, but lower slopes and high-energy streams. Results allow focusing efforts on environmental policy instruments to implement adaptation measures to sustainability of the CS.

Keywords: vulnerability model, coastal zone, climate change, natural hazards, pressure index, fragility index, indicators.
\end{abstract}




\section{Introduction}

Sustainability should be a key element of the agendas and lines of action of every city or country. As an essential component of any public policy, sustainability requires three key aspects: 1) long-term perspective, 2) to generate stable systems, and 3 ) to integrate environmental, social, economic and institutional areas [1]. The third aspect is interrelated to the current environmental status of a region, and the pressure exerted on it by the socioeconomic sphere, favoring regions with more or less capacity to address these pressures, or its differential vulnerability (V). Impacts of natural variability (NV) and climate change (CC) like atmosphere and ocean warming, sea level rise, increased intensity and/or duration of drought in some regions, and increased concentrations of greenhouse emissions, constrain researchers and decision-makers to assess most vulnerable sites to these threats (understanding $\mathrm{V}$ as the inability to cope with adverse effects), and implement actions to comply with this phenomenon, moderate damage and take advantage of emerging opportunities or to adapt [2-3]. In this regard, coastal zone is vulnerable to NV and CC because $60 \%$ of the human population and eight of the top ten largest cities in the world are located in this [4-7]. Mexico is the $13^{\text {th }}$ country with the longest coastline in the world $(\approx 11,200 \mathrm{~km})$ and Baja California Sur (and its 5 municipalities) is the longest coastline state; and it possesses the highest average annual population growth rate $-4.5 \%$ from $2005-2010$ period - in the country [811].

To achieve sustainable development, it is necessary to consider not only the environmental protection against pressures exerted by humans (eco-centric V), but also must be considered potential impacts of key threats from NV and CC to life, health and welfare of humans (anthropocentric V) [12-16]. Since V can be expressed as an inverse function of sustainability level of a particular development model, then it is essential to identify, estimate and reduce $\mathrm{V}$ of cities to key impacts of $\mathrm{NV}$ and $\mathrm{CC}$, implementing adaptive actions, and then enhance sustainability [17-18]. In other words, a city or society is more sustainable to the extent that it is less vulnerable. One way to assess the $\mathrm{V}$ is using appropriate indicators and indices across models. The assessment and monitoring of $\mathrm{V}$ models in coastal cities should be able to influence the country's environmental policy, guiding the different actors and providing timely information for decision making and awareness in society about the potential impact processes and problems that affect phenomena [19-20]. Vulnerability models need to integrate indicators, which are key parameters, aimed at providing information, describe and represent an aspect of the state of a phenomenon, environment or area, and its relationship to human activities, with an added meaning greater than its directly associated own value; and indices, defined as a set of aggregated or weighted indicators [21-24]. We designed a novel model that allowed us to evaluate the coastal $\mathrm{V}$ to potential effects of sea level rise and flooding by torrential rains caused by NV and CC, within regionalized environmental units, at the largest coastal population community in Baja California Sur state. 


\section{Method}

The case of study La Paz (CS) contains the major population center of Baja California Sur state, and minor coastal communities. It is located northwest Mexico, at Gulf of California southern region near the tip of Baja peninsula; and presents diverse coastal environments and ecotonal zones defined by various studies [25-30] within a coastal strip that includes wide coastal plains, short watershed mountain ranges, pristine and protected areas, coastal lagoons, sandbars and many mangrove patches. CS was characterized based on watersheds (number and magnitude order streams, slopes, basin height and length), topography (from $3 \mathrm{~d}$ model and official topographic maps), land use (urban, rural and agricultural uses), vegetation (natural or modified), bathymetry (from cartographic interpolations), natural protected areas (national important bird area or AICA, federal protected areas and Ramsar wetlands), and social factors from 2005-2010 censuses (population and housing data). Three base maps (physiographic, land use-vegetation and watersheds) were developed and corrected with field observation to finest scale of 1:20,000, delimitating CS with a spatial polygon clipping derived from coastline and 100 meters contour union, based on a combined digital elevation model from various sources [31-33]. All information was generated in geographic information system (GIS) and Universal Transverse Mercator projection, WGS84 datum and units in meter. With the intersection of watersheds, land use-vegetation and landform layers in spatial analysis on GIS platform, we obtained different homogenous environmental units (EnvU) in terms of their attributes. Every EnvU name was generated from watershed $(\mathrm{A}=$ Azabaches stream, $\mathrm{B}=$ Bahía Pichilingue, $\mathrm{C}=$ Bahía Falsa estuary, $\mathrm{D}=$ Puerto Gato estuary, E=Punta Prieta, $F=$ Coromuel beach, $G=E l$ Cajoncito stream, $\mathrm{H}=$ Tamales stream, $\mathrm{I}=\mathrm{E}$ l Novillo stream, $\mathrm{J}=\mathrm{El}$ Centenario (town), $\mathrm{K}=$ Garambullo stream), physiographic (1=active dune, 2=floodplain, 3=floodplain-cemented rocky soil, 4=lying rolling hill with slope, $5=$ low mountain range), and land use and vegetation codes ( $\mathrm{a}=$ agricultural, $\mathrm{b}=$ urban, $\mathrm{c}=$ airport, $\mathrm{d}=$ wastewater plant, $\mathrm{e}=$ secondary vegetation, $\mathrm{f}=$ crasicaule shrub, $\mathrm{g}=$ Mangrove swamps, $\mathrm{h}=$ mesquite, $\mathrm{i}=$ sarcocaule shrub, $\mathrm{j}=$ deciduous forest, $\mathrm{k}=$ coastal dune vegetation, $\mathrm{l}=$ halophytic plants).

Conceptual model of vulnerability was proposed based on causal-model structure - where a system state or fragility is modified due to the application of a force or pressure - and modified from OECD [21] and other authors [34-37]. The vulnerability model integrated both external and internal factors in the pressure index; and physical, environmental and socioeconomic factors within fragility index. Normalization was required obtain 0 to 1 dimensionless quantities and compare index values between them in each EnvU, so Nijkamp et al. [38] method is used. Normalization allowed classifying index and sub-index value into five categories by percentile method (very low, low, medium, high and very high), assigning a color code to each category for representing on a map. 


\section{Results and discussion}

The CS total area was $437 \mathrm{~km}^{2}$ with 74 EnvU and 170 clusters (fragmented EnvU) derived from regionalization and almost $50 \%$ of EnvU were in contact with coastal line. La Paz main urban area represented only $15 \%$ of all CS and just $8 \%$ (central east area) showed high population density in 2010 census, higher than national average (57 people per $\mathrm{km}^{2}$ ) and similar in one EnvU to Mexico City $(5,679$ and 5,920 per $\mathrm{km}^{2}$ respectively). Nearly $50 \%$ of EnvU are inhabited. Coastal vulnerability index (CVI) was implemented in 74 EnvU and took into consideration three components:

- $\quad$ Fixed part, defined by CVI and two $1^{\text {st }}$ order sub-indices: Fragility (FI) with the following $2^{\text {nd }}$ order weighted sub-indices, richness (Irb), naturalness (In), geophysics (Igf), hydrologic risk (Ie), and population at risk (Ics); and Pressure (PI) with the next $2^{\text {nd }}$ order weighted sub-indices, demography (Ide), environmental impact activities (Iai), loss of naturalness (Ipn), relative mean sea level change $(\mathrm{Cnm})$, coastline erosion/accretion $(\mathrm{Eac})$, potential flooding (Pall) (Tables 1 and 2).

- $\quad$ Adaptable part, defined by 42 indicators to evaluate $2^{\text {nd }}$ order sub-indices.

- Mathematical component, to standardize and integrating indices by simple addition, with weighting algorithms by expert consulting work. Once a normalized value assigned to each EnvU for every sub-indices, CVI was calculated as the sum of the two $1^{\text {st }}$ order sub-index values:

$$
C V I=\sum \text { (Fragility, Pressure) }
$$

where Fragility (FI) was obtained from the sum of $I r b+I n+I g f+I e+I c s$; Pressure (PI) was obtained from the sum of Ide+Iai+Ipn+Cnm+Eac+Pall.

FI map (Figure 1(a)) showed high and very high fragile EnvU located mainly southern and western part of the CS. Most fragile EnvU was I2f (FI=1.0), located south of the alluvial plain at El Novillo basin, because its high vegetation richness (24 Crassicaule shrub species) and located within an AICA area, with slope $\leq 2$ in $88 \%$ of its surface, high potential energy streams, high rate of total annual precipitation uptake, and highest magnitude Strahler's stream order.

PI map (Figure 1(b)) showed high and very high pressure units located at eastern and central coast of the CS. Most pressure EnvU was G2b (PI=1.0), located central east of CS, at La Paz urban area; and contributing indicators were high percentage of economically active population (with potential impacts), 100\% of urban activities in EnvU, disturbed land high ratio, and presence of protected areas in disturbed lands (AICA and Ramsar wetlands).

CVI results using mathematical integration method (Figure 2) showed CS north portion with very low and low CVI; central and west portion of area, with low and medium CVI mainly; and central east and south of CS with high and very high CVI within urban region (capital city and vicinity) and natural zones without human pressure. Only a quarter (28) of all EnvU exhibited high to very high fragility, representing approximately $61 \%$ of CS. Conversely, La Paz and some central EnvU located in urban growth areas (10 EnvU's), experienced high to very high levels of pressure, corresponding about $17 \%$ of all CS. 
Table 1: Sub-index (I) and indicator estimate for FI.

\begin{tabular}{|c|c|c|}
\hline I & EQUATION & INDICATORS \\
\hline \multirow{3}{*}{ Irb } & \multirow{3}{*}{$\begin{array}{c}\operatorname{Irb}=\operatorname{irf}+ \\
\left(i r a^{*} 0.5\right)+r p f\end{array}$} & $\begin{array}{l}\text { Flora species richness (irf) in each EnvU, based on official } \\
\text { vegetation map data }\end{array}$ \\
\hline & & $\begin{array}{l}\text { Weighted bird species richness index (ira), \# species } \\
\text { reporting in each AICA-EnvU binding }\end{array}$ \\
\hline & & $\begin{array}{l}\text { Forest representation (rpf), \# EnvUs by type of land use and } \\
\text { vegetation }\end{array}$ \\
\hline \multirow{4}{*}{ In } & \multirow{4}{*}{$\begin{array}{l}\text { In }=n_{2012}+\operatorname{csn}_{1994-} \\
2012+(\text { frg*0.8) }+ \\
\quad(\text { anp*0.6) }\end{array}$} & $\begin{array}{l}\text { Natural land cover in } 2012\left(\mathrm{n}_{2012}\right) \text {, by calculating loss trend } \\
\text { per EnvU from [39-40] }\end{array}$ \\
\hline & & Land cover change from 1994 to 2012 ( $\operatorname{csn}_{1994-2012) .}$ \\
\hline & & $\begin{array}{l}\text { Fragmentation index (frg), \# fragments by EnvU, less } \\
\text { fragmented, less fragile }\end{array}$ \\
\hline & & $\begin{array}{l}\text { Protected-area index (anp), presence/absence of federal or } \\
\text { state protected areas, AICA, Ramsar, in each EnvU }\end{array}$ \\
\hline \multirow{5}{*}{ Igf } & \multirow{5}{*}{$\begin{array}{l}I g f=i g m+p p+ \\
r p t+i p e+c s a<2\end{array}$} & $\begin{array}{l}\text { Weighted landform index (igm), more weighted for lowland } \\
\text { areas }\end{array}$ \\
\hline & & $\begin{array}{l}\text { Weighted watershed slope (pp) of each EnvU, using digital } \\
\text { elevation model (greater weight to low slopes) }\end{array}$ \\
\hline & & Landform representativeness (rpt), \# EnvU by landform type \\
\hline & & $\begin{array}{l}\text { Stream energy index (ipe), basin hypotenuse }+ \text { average slope } \\
\left({ }^{\circ}\right) \text { of each EnvU }\end{array}$ \\
\hline & & $\begin{array}{l}\text { Land cover ratio with slope } \leq 2^{\circ}(\operatorname{csa}<2) \text {, for each EnvU, } \\
\text { based on digital elevation model }\end{array}$ \\
\hline \multirow{4}{*}{ Ie } & \multirow{4}{*}{$\begin{array}{c}I e=d a+i c p t+ \\
r p h+i p a\end{array}$} & Stream density (da), \# of streams / EnvU area \\
\hline & & $\begin{array}{l}\text { Infiltration capacity index (icpt), modified from [41] for each } \\
\text { EnvU }\end{array}$ \\
\hline & & Watershed representativeness (rph), \# EnvU by watershed \\
\hline & & $\begin{array}{l}\text { Potential flood affectation index (ipa), \# of runoff }+ \\
\text { maximum Strahler order of stream segments }+ \text { watershed } \\
\text { mean slope }(\%) \text { in each EnvU }\end{array}$ \\
\hline \multirow{4}{*}{ Ics } & \multirow{4}{*}{$\begin{array}{c}\text { Ics }=\text { an }+ \text { dean }+ \\
\text { te }+ \text { dete }+ \text { in }+ \\
\text { dein }+v i+\text { devi }\end{array}$} & $\begin{array}{l}\text { Illiterate population over age } 15 \text { indicator (an), illiterate } \\
\text { population density (dean), from } 2010 \text { Census data, by EnvU }\end{array}$ \\
\hline & & $\begin{array}{l}\text { Older population indicator (te) and older population density } \\
\text { (dete), persons } 65 \text { years or older, from } 2010 \text { Census data, by } \\
\text { EnvU }\end{array}$ \\
\hline & & $\begin{array}{l}\text { Children population indicator (in) and children population } \\
\text { density (dein). Children under two years of age, from } 2010 \\
\text { Census data, by EnvU }\end{array}$ \\
\hline & & $\begin{array}{l}\text { Total number of dwellings (vi) and housing density (devi) } \\
\text { from } 2010 \text { Census data, by EnvU }\end{array}$ \\
\hline
\end{tabular}


Table 2: Sub-index (I) and indicator estimate for PI.

\begin{tabular}{|c|c|c|}
\hline $\mathrm{I}$ & EQUATION & INDICATORS \\
\hline \multirow{3}{*}{ Ide } & \multirow{3}{*}{$\begin{array}{l}\text { Ide }=\left(d p_{10} * 0.5\right) \\
\quad+c d p_{05-10}+ \\
\quad(\text { pea } * 0.5)\end{array}$} & $\begin{array}{l}\text { Population density }\left(\mathrm{dp}_{10}\right) \text {, total EnvU people/EnvU area in } \\
\text { hectares, from } 2010 \text { Census }\end{array}$ \\
\hline & & $\begin{array}{l}\text { Demographic change (cdpo5-10), geometric population } \\
\text { growth rate for } 2005-2010 \text { periods }\end{array}$ \\
\hline & & $\begin{array}{l}\text { Economically active population (pea), from } 2010 \text { Census } \\
\text { data, by EnvU }\end{array}$ \\
\hline \multirow{3}{*}{ Iai } & \multirow{3}{*}{$\begin{array}{l}\text { Iai }=\text { paa }+ \\
(\text { pau*0.8)+ } \\
\left(\text { par*0.5) }^{*}\right)\end{array}$} & $\begin{array}{l}\text { Total agricultural area (paa), area under agriculture in each } \\
\text { EnvU }\end{array}$ \\
\hline & & $\begin{array}{l}\text { Total urban area (pau), from modified land use map in each } \\
\text { EnvU }\end{array}$ \\
\hline & & \begin{tabular}{|l} 
Total rural area (par), considering secondary shrub \\
vegetation and/or presence of rural localities by EnvU
\end{tabular} \\
\hline \multirow{3}{*}{ Ipn } & \multirow{3}{*}{$\begin{aligned} \text { Ipn }= & \text { pst }+ \text { panp } \\
& + \text { tst }\end{aligned}$} & $\begin{array}{l}\text { Land-use change rate (pst), by dividing loss trend of natural } \\
\text { cover between total area of each EnvU. Modified from [39- } \\
40]\end{array}$ \\
\hline & & $\begin{array}{l}\text { Affected protected area (panp), land-use change rate * \# of } \\
\text { protected areas in each EnvU }\end{array}$ \\
\hline & & $\begin{array}{l}\text { Natural land cover trend (tst), natural calculated area in } 2012 \\
\text { minus natural area in 1994, between ranging period (ha/year) }\end{array}$ \\
\hline \multirow{5}{*}{$\mathrm{Cnm}$} & \multirow{5}{*}{$\begin{array}{l}C n m=(g c h * 0.5) \\
+(g c * 2)+c s \% \\
+(s l r * 0.5)+ \\
\quad(r m m * 0.5)\end{array}$} & $\begin{array}{l}\text { Watershed geomorphology (gch); ranking: low mountain } \\
\text { range (1), lying rolling hill with declines (2), active dunes } \\
\text { (3), floodplain cemented rocky soil (4), floodplain (5) }\end{array}$ \\
\hline & & $\begin{array}{l}\text { Coastal geomorphology (gc); ranking: steep ocean cliffs or } \\
\text { rocky coast (1), middle cliff, indented coast (2), lower cliffs, } \\
\text { plains/floodplains (3), pebble beaches, estuaries, lagoons (4), } \\
\text { barrier coast, spits, sandy beaches, deltas, mangrove, coral } \\
\text { reef (5) }\end{array}$ \\
\hline & & $\begin{array}{l}\text { Coastal slope percent (cs\%); } 1 \mathrm{~km} \text { buffer each side of } \\
\text { coastline derived from DEM and bathymetry; ranking: } \\
\leq 0.6 \%(5), \leq 0.9 \%(4), \leq 1.3 \%(3), \leq 1.9 \%(2),>1.9 \% \text { (1) }\end{array}$ \\
\hline & & $\begin{array}{l}\text { Relative sea level change (slr); with a calculated increasing } \\
\text { trend of } 1.04 \mathrm{~mm} / \mathrm{yr} \text {; ranking: EnvU with coastline (3), EnvU } \\
\text { with no coast (0). Adapted from }[34,37]\end{array}$ \\
\hline & & $\begin{array}{l}\text { Tidal range's impact indicator (rmm); ranking: EnvU with } \\
\text { coastline (3), EnvU with no coastline (0). Adapted from [34] }\end{array}$ \\
\hline \multirow[t]{2}{*}{ Eac } & \multirow[t]{2}{*}{$E a c=t e c+r l c$} & $\begin{array}{l}\text { Coastal erosion rate (tec); shoreline displacement during an } \\
\text { observation period: DLC/(year2-year1), where DLC=current } \\
\text { area less area of previous date/current coastal length }\end{array}$ \\
\hline & & $\begin{array}{l}\text { Coastline percentage (rlc); coastal length/EnvU total } \\
\text { perimeter }\end{array}$ \\
\hline \multirow[t]{2}{*}{ Pall } & \multirow[t]{2}{*}{ Pall $=s a e+d a e$} & $\begin{array}{l}\text { Potential for runoff (sae) in each EnvU; } 200 \mathrm{~m} \text { buffer for } \\
\text { Strahler stream order } 5 \text { and } 6,100 \mathrm{~m} \text { buffer for } 3 \text { and } 4,50 \mathrm{~m} \\
\text { buffer for } 1 \text { and } 2\end{array}$ \\
\hline & & $\begin{array}{l}\text { Potential runoff density (dae); potential for runoff/total area, } \\
\text { in each EnvU }\end{array}$ \\
\hline
\end{tabular}




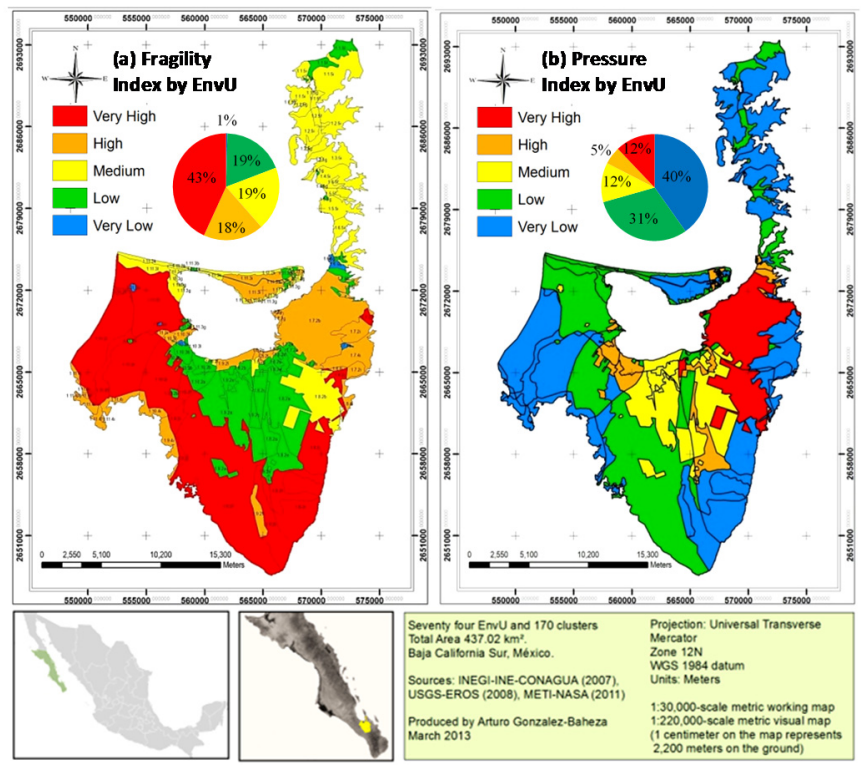

Figure 1: First order sub-index maps. (a) FI map with fragile units located southern and western CS. (b) PI map with higher pressure units located primarily eastern and central CS. Circle graph represents area (\%) of five-category FI and PI classification.

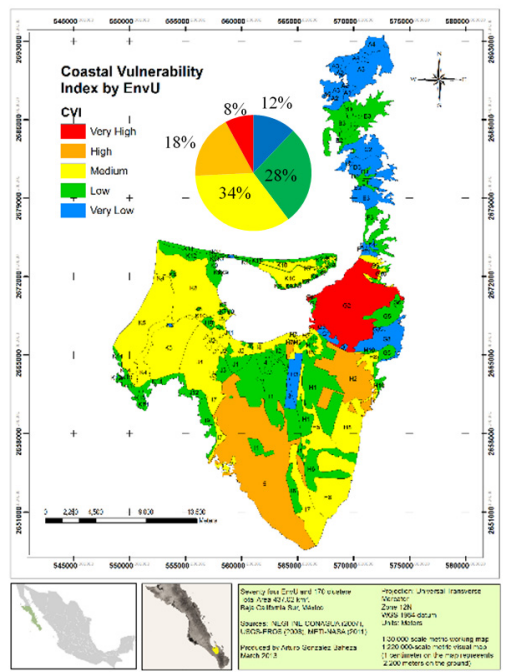

Figure 2: Coastal vulnerability index. Most vulnerable units were located at urban zone of capital city, urban growth area and El Novillo basin (red and orange areas). Circle graph represents area (\%) of fivecategory CVI classification. 
The global CS had Medium FI (Mean=0.52, \pm 0.23 SD), Low PI (Mean=0.31, $\pm 0.23 \mathrm{SD}$ ) and Low CVI (Mean $=0.31, \pm 0.17 \mathrm{SD}$ ). Only one very high CVI EnvU (G2b, Figure 2) was due to about $69 \%$ sum contribution of 2 fragility (Igf and Ics) and 3 pressure (Ide, Iai and Ipn) sub-indices. High CVI EnvU (H2b) was due to $73 \%$ sum contribution of Igf (fragility), Ide, Iai, Ipn and Cnm (pressure) subindices. It was different for I2f high CVI, were Irb, Igf, Ie (fragility) and Pall (pressure) sub-indices contributed approximately $78 \%$; it means high CVI was due to fragility, not pressure like people density $\left(<1\right.$ people per $\left.\mathrm{km}^{2}\right)$.

Fragility on total CS (Figure 3) was determined mainly by very high values of In (mean $0.65, \pm 0.35 \mathrm{SD}$ ) over $50 \%$ of all EnvUs, and very high values of Irb (mean $0.49, \pm 0.42 \mathrm{SD}$ ) and $\operatorname{Ig} f$ (mean $0.51, \pm 0.32 \mathrm{SD}$ ) in more than $43 \%$ and $28 \%$ of total EnvUs respectively. It is because a lot of the CS lead on some type of natural protected area, with high flora and bird species richness, and it is placed on an extensive alluvial fan.

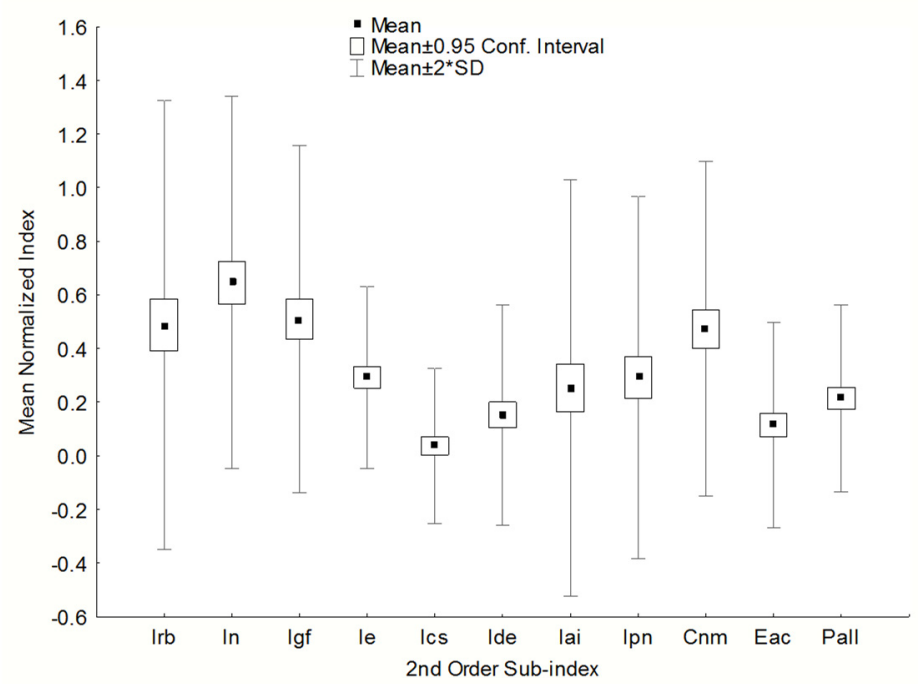

Figure 3: Mean normalized contribution of each sub-index based on its average value in total $\mathrm{CS}$.

Pressure on the whole CS (Figure 3) was due to the contribution of very high values of Iai (mean 0.25, $\pm 0.39 \mathrm{SD}$ ), Ipn (mean 0.29, $\pm 0.34 \mathrm{SD}$ ) and Cnm (mean $0.47, \pm 0.31 \mathrm{SD}$ ) in $28 \%, 9 \%$ and $24 \%$ of all EnvUs, related to change of land use due to due to agricultural activities and growing urban areas as well as natural vegetation impacts by anthropogenic activities and its transformation to secondary vegetation; coastal type and watershed geomorphology with low slope and adjacent to coastline also contributed. It is noteworthy that Ide index did not contribute in most units with high values as expected, so population density is not the most weighted indicator on the pressure index for this region. As assessed in this study, about $30 \%$ of EnvU showed high to very high FI (Figure 4) and were 
located at the east and south of the CS, including capital city. Instead of, less than $7 \%$ of EnvU showed high to very high PI (Figure 4), located basically in urban areas and surroundings.

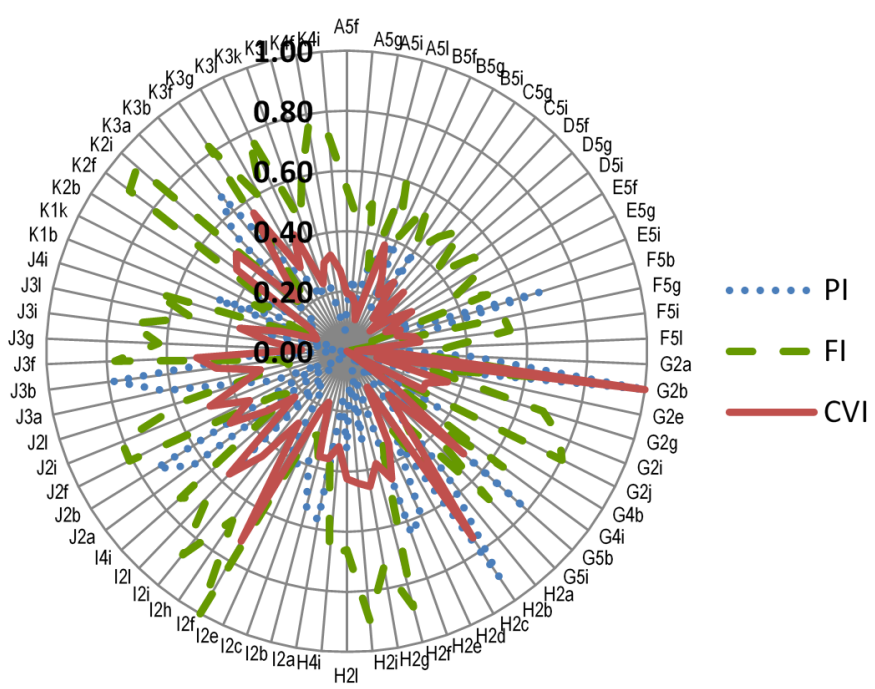

Figure 4: PI, FI and CVI index values for each EnvU.

Proposed model's contribution and its results showed the CS is well represented by homogeneous and geography-landscape bounded EnvU; physicalbiological and social sub-indices proposed in the CVI model are easily accessible, estimated with available data in the country, with a relatively small required number of parameters to give a representation of reality, and easily communicate results to users. The maps and data presented here can be viewed as a sustainable planning tool for the region.

\section{References}

[1] OSERM \& UMH, Herramienta avanzada para la gestión sostenible y desarrollo del sistema de información y participación en las Reservas de Biosfera. Proyecto: RB Digital. Ministerio de Industria, Turismo y Comercio, España. Subvención: 37.198,14 eur., 2010.

[2] Ivanova, A. \& Gámez, A.E., (eds). Plan Estatal de Acción ante el Cambio Climático para Baja California Sur (PEACC-BCS). México, 2012.

[3] Stocker, T.F., Qin, D., Plattner, G.-K., Tignor, M., Allen, S.K., Boschung, J., Nauels, A., Xia, Y., Bex, V. \& Midgley, P.M., (eds). Climate Change 2013: The Physical Science Basis. Contribution of Working Group I to the Fifth Assessment Report of the Intergovernmental Panel on Climate Change. Cambridge University Press, Cambridge, United Kingdom and New York, 2013. 
[4] United Nations Environment Programme (UNEP). UNEP Year Book. http://www.unep.org/yearbook/2009/

[5] UN Atlas of the Ocean. The ever more popular coasts. Human Settlements on the Coast, 2010, http://www.oceansatlas.org

[6] Benassai, G., Brebbia, C. A., \& Rodríguez, G. R. (Eds.). Coastal Processes II (Vol. 149). Wit Press, 2011.

[7] Guanghui W., Liu, Y., Wang, H., Wang, X., A comprehensive risk analysis of coastal zones in China. Estuarine, Coastal and Shelf Science, vol. 140, pp. 22-31, 2014.

[8] Azuz-Adeath, I. \& Rivera-Arriaga, E., Descripción de la dinámica poblacional en la zona costera mexicana durante el periodo 2000-2005. Pap. poblac (online). 15(62), pp. 75-107, 2009.

[9] Seingier, G., Espejel, I. \& Fermán-Almada, J.L., Cobertura vegetal y marginación en la costa mexicana. Investigación ambiental 1(1), pp. 54-69, 2009.

[10] Azuz-Adeath, I., Espejel, I., Rivera-Arriaga, E., Ferman, J.L. \& Seingier, G., Referentes internacionales sobre indicadores e índices. Historia y estado del arte (Chapter 6). Cambio Climático en México un Enfoque CosteroMarino, eds. E. Rivera-Arriaga, I. Azuz-Adeath, L. Alpuche Gual \& G.J. Villalobos-Zapata, Universidad Autónoma de Campeche, CETYSUniversidad, Gobierno del Estado de Campeche. pp. 845-858, 2010.

[11] Instituto Nacional de Estadística y Geografía (INEGI). Censo de Población y Vivienda 2010. Cuestionario básico, http://www3.inegi.org.mx

[12] United Nations (UN). Report of the United Nations Conference on Environment and Development. Rio de Janeiro, Brazil. A/CONF.151/26/Rev. 1, vol. I, 1993.

[13] INE-SEMARNAT, México: Cuarta Comunicación Nacional ante la Convención Marco de las Naciones Unidas sobre el Cambio Climático. Comisión Intersecretarial de Cambio Climático. $1^{a}$ Ed., pp. 119-171, 2009.

[14] Buenfil, J., Adaptación a los impactos del cambio climático en los humedales costeros del Golfo de México. Secretaría de Medio Ambiente y Recursos Naturales-Instituto Nacional de Ecología, México, Vol. I, pp. 103$187,2009$.

[15] Bedsworth, L.W. \& Hanak, E., Adaptation to Climate Change: a review of challenges and tradeoffs in six areas. Journal of the American Planning Association, 76(4), pp. 477-495, 2010.

[16] United Nations (UN). The future we want. General Assembly, Sixty-sixth session. Agenda item 19. A/RES/66/288, 2013.

[17] Cardenal, S.L., De la vulnerabilidad a la sostenibilidad: Ejes de transformación para una sociedad en condiciones crónicas de riesgo. In Memorias del foro sobre el huracán Mitch: Huracán Mitch, reflexiones y lecciones. Nicaragua. Red Nicaragüense por la Democracia y el Desarrollo Local; Alemania. Fundación Heinrich Böll, pp. 57-77, 1999.

[18] Marsden, T., Mobilities, vulnerabilities and sustainabilities: exploring pathways from denial to sustainable rural development. Sociologia Ruralis, 49, pp. 113-131, 2009. 
[19] Seingier, G., Espejel, I., Fermán-Almada, J.L., Montaño-Moctezuma, G., Azuz-Adeath, I., \& Aramburo-Vizcarra, G., Mexico's coasts: Half-way to sustainability. Ocean \& Coastal Management, 54(2), pp. 123-128, 2011.

[20] Vázquez-González, C., Fermán-Almada, J.L., Moreno-Casasola, P., \& Espejel, I., Scenarios of vulnerability in coastal municipalities of tropical Mexico: An analysis of wetland land use. Ocean \& Coastal Management, 89, pp. 11-19, 2014.

[21] Organization for Economic Co-Operation and Development (OECD). OECD Core Set of Indicators for Environmental Performance Reviews, Environmental Monograph \# 83, Paris, http://www.fao.org

[22] Dale, V.H. \& Beyeler, S.C., Challenges in the development and use of ecological indicators. Ecological Indicators 1, pp. 3-10, 2001.

[23] United Nations. Department of Economic. Indicators of sustainable development: Guidelines and methodologies. United Nations Publications, pp. 9-85, 2007.

[24] UNEP, Proposal of the Working Group on Environmental Indicators to the Forum of Ministers of the Environment of Latin America and the Caribbean. UNEP/LAC-IGWG.XIX/4.Rev.2, 2014. http://www.pnuma.org/

[25] Shreve F., Vegetation of the Sonoran Desert. Carnegie Institute of Washington Publications 591, pp. 1-192, 1951.

[26] Wiggins, I. L., Flora of Baja California. Stanford University Press, 1980.

[27] Rzedowski, J., \& Reyna-Trujillo, T., Divisiones florísticas. In: Tópicos fitogeográficos (provincias, matorral xerófilo y cactáceas) IV.8.3, Atlas Nacional de México, 2, 1990.

[28] Peinado, M., Alcaraz, F., Delgadüxo, J. \& Aguado, I., Fitogeografía de la península de Baja California, México. Anales Jard. Bot. Madrid 51(2), pp. 255-277, 1994.

[29] de la Luz, L., Luis, J., Navarro, P., Juan, J., \& Breceda, A., A transitional xerophytic tropical plant community of the Cape Region, Baja California Journal of Vegetation Science, 11(4), pp. 555-564, 2000.

[30] Garcillán, P.P., \& Ezcurra, E., Biogeographic regions and $\beta$-diversity of woody dryland legumes in the Baja California peninsula. Journal of Vegetation Science, 14(6), pp. 859-868, 2003.

[31] Cotler H., Garrido A., Mondragón R., Díaz A., Delimitación de cuencas hidrográficas de México, a escala 1:250,000, INEGI-INE-CONAGUA. Documento técnico. México, 2007.

[32] USGS-EROS. 2008. Raster image 1-Arc Second (30 m) National Elevation Dataset (NED). U.S. Geological Survey. http://eros.usgs.gov/\#/Home

[33] METI-NASA. 2011. ASTGTM2_N24W111 Image. ASTER GDEM version 2. Earth Remote Sensing Data Analysis Center. ASTER GDS User Service http://www.gds.aster.ersdac.or.jp/gds_www2002/service_e/

[34] Thieler, E.R. \& Hammar-Klose, E.S., National Assessment of Coastal Vulnerability to Sea-level Rise, Preliminary Results for the US Pacific Coast. U.S. Geological Survey, 2000, http://pubs.usgs.gov/of/of00-178 
[35] Moss, R.H., Brenkert, A.L., \& Malone, E.L., Vulnerability to climate change: a quantitative approach. Pacific Northwest National Laboratory (PNNL-SA-33642). Prepared for the US Department of Energy, 2001.

[36] Füssel, H.M., Vulnerability: a generally applicable conceptual framework for climate change research. Global Environmental Change, 17(2), pp. 155167, 2007.

[37] Tallis, H.T., Ricketts, T., Guerry, A.D., Wood, S.A., Sharp, R., Nelson, E., Ennaanay, D., Wolny, S., Olwero, N., Vigerstol, K., Pennington, D., Mendoza, G., Aukema, J., Foster, J., Forrest, J., Cameron, D., Arkema, K., Lonsdorf, E., Kennedy, C., Verutes, G., Kim, C.K., Guannel, G., Papenfus, M., Toft, J., Marsik, M., y Bernhardt, J., InVEST 2.2.0 User's Guide. The Natural Capital Project, Stanford, 2011.

[38] Nijkamp, P., Rietveld, P., \& Voogd, H., Multicriteria evaluation in physical planning. Amsterdam: North-Holland, pp. 65-100, 1990.

[39] Challenger, A., Dirzo, R., López- Acosta, J.C., Mendoza, E., Lira-Noriega, A., Cruz, I., Flores-Martínez, A., González-Espinosa M., Factores de cambio y estado de la biodiversidad (Chapter 1). Capital natural de México, vol. II: Estado de conservación y tendencias de cambio, CONABIO, México, pp. 45-56, 2009.

[40] SEMARNAT, Uso de Suelo y vegetación en México: Vegetación potencial primaria, 1976, 1993, 2002 y 2007. Compendio de Estadísticas Ambientales 2012. http://app1.semarnat.gob.mx/dgeia/Compendio_2012/

[41] Cruz-Falcón, A., Vázquez-González, R., Ramírez-Hernández, J., NavaSánchez, E.H., Troyo-Diéguez, E., Rivera-Rosas, J., \& Vega-Mayagoitia, J.E., Precipitación y recarga en la cuenca de La Paz, BCS, México. Ecosistemas y Recursos Agropecuarios, 27(3), pp. 251-263, 2011. 